\title{
A Ê HOĈU KAKO MOGU - NEKOLIKO MISLI O HRVATSKOGLAGOLJSKOJ PISANOJ BAŠTINI
}

Marija-Ana Dürrigl

Staroslavenski institut

Demetrova 11

HR 10000 Zagreb

duerrigl@stin.hr

\author{
UDK: 003 \\ 930.85(497.5Senj) \\ Prethodno priopćenje \\ Ur.: 2021-03-17
}

U radu se ukratko, na temelju nekoliko tipičnih iskaza glagoljaških pisara, kompilatora i prevoditelja, sažimlju neki pogledi na glagoljsku tekstnu zajednicu. Kroz odabrane se citate otkriva povezanost raznorodnoga sadržaja rukopisa (a neki od njih slagani su po idealu "što općenitijega" materijala, kao da se stremilo kakovu srednjovjekovnom enciklopedizmu, čemu je najbliže Petrisov zbornik iz 1468. godine) s konkretnim okruženjem, odnosno publikom za koju su tekstovi pisani, te s polifunkcionalnošću velikoga broja prepisanih, prevedenih ili kompiliranih sastava.

To je postupak kroz koji je ostvaren specifičan fenomen "migracije", pokretljivosti i prilagođavanja raznih predložaka i izvora, čime su glagoljaši hrvatsku glagoljsku pisanu riječ učinili dijelom zajedničke europske srednjovjekovne kulturne, duhovne i književne tradicije. zbornici

Ključne riječi: hrvatskoglagoljska pisana baština, čitateljska zajednica, pisari,

\section{Uvod}

U znanstvenom opusu msgr. dr. Mile Bogovića značajno mjesto zauzima glagoljaška problematika jer je proučavao i "bremenitu granu hrvatskoga glagoljaštva"1. Kao smjerokaze ili odmorišta na kojima zastajemo uzimamo dobro poznate citate iz kojih kao da progovaraju glagoljaši "o sebi samima" toposom skromnosti i nedostatnosti, ali i toposom potrebe da se piše. U nastojanju oko detaljnije analize knjiških i književnih žanrova hrvatske glagoljske tradicije možemo, dakle, poći slijedeći paratekstualne navode koji su poput odbljesaka svjetionika na obzoru povijesti knjige, čitanja, pa i povijesti mentaliteta. Na ovom se mjestu podastiru tek neka zapažanja i poticaji za daljnja istraživanja;

${ }^{1}$ M. BOGOVIĆ, 2004, 247. 
na neki je način i preširok zahvat da se usmjeri na jedan problem ili pojavu, a istovremeno bez pretenzija da se podastre dubinska analiza.

Odabrani citati sažeto izražavaju "proces" vezan uz postupke hrvatskih glagoljaša, iako je sam pojam glagoljaši prilično amorfan. Taj pojam zapravo i prelazi granice (jednoga) alfabeta, tradicije i književnosti. Kroz citate se otkriva povezanost raznorodnoga sadržaja rukopisa (a neki od njih slagani su po idealu što općenitijega materijala, kao da se stremilo kakovu srednjovjekovnom enciklopedizmu) sa stvarnim kulturnim i društvenim okruženjem u kojem su nastajali.

Svi su ti postupci vezani i uz pragmatičnu stranu oblikovanja zbornika i liturgijskih knjiga, kao i uz primatelje za koje su knjige namijenjene; sve se to može vezati uz tekstnu, odnosno glagoljsku čitateljsku zajednicu ${ }^{2}$ koju (doduše, s današnjega zrenika i na temelju dosta oskudnoga materijala) nastojimo rekonstruirati, uz njezin odnos prema tekstovima - ali i uz odnos pisca/pisara prema publici i sadržajima koje piše i/ili prevodi. U tim kratkim navodima pisari, pisci, kompilatori (nažalost, često anonimni) izravno se obraćaju primatelju ${ }^{3}$ što je postupak privlačenja pozornosti, ali i stvaranje duhovnoga, misaonoga i osjećajnoga zajedništva, odnosno okruženja (setting) za čitanje ili slušanje određenih sadržaja. Stoga ti navodi u prvom licu jednine ne govore samo "o autoru", dakle nisu samo specifična autoreferencija ili komentar u prolozima, već smatramo kako su indikativni za cijelu čitateljsku zajednicu. Pritom mislimo na različite faze ili stadije u nastanku, oblikovanju rukopisa kakav je do nas došao: prvo je pisac-kompilator bio čitatelj, rjeđe možda slušatelj (pod'stolom ' meštar' mrvice pobrah'); ${ }^{4}$ zatim on piše, prevodi, prepisuje i kompilira svjestan svoje ograničenosti (to pisa ruka greš'na), ali ipak osjeća dužnost da druge pouči (nam'

${ }^{2}$ Pojam "čitateljske zajednice" u hrvatsku je filološku medievistiku uvela, pišući o glagoljskim korizmenim propovijedima, Andrea Radošević (A. RADOŠEVIĆ, 2016), a detaljno je razrađen u radu o Drugom beramskom brevijaru iz 15. stoljeća (A. RADOŠEVIĆ - M.-A. DÜRRIGL, 2020). Premda posvećena produkciji i korištenju brevijara kao tipične knjiške vrste, zaključci se studije u dobroj mjeri mogu primijeniti i na neliturgijski dio glagoljskoga nasljeđa o kojemu je većim dijelom riječ u ovom razmatranju.

${ }^{3}$ Teškoće su brojne u pokušaju da se pogledi suvremene književne teorije i analize primijene na srednjovjekovne tekstove - primjerice, obraća li se autor/pripovjedač srednjovjekovnoga nabožnoga i poučnoga štiva primatelju kao unutar- ili izvanknjiževnoj kategoriji? Osim toga, kad se govori o golemoj većini hrvatskoglagoljskih tekstova, riječ je o prijevodima i prilagodbama, tj. prenosi se nešto već postojeće (usp. A. MINNIS, 2010, 102), pa ćemo stoga katkad upotrijebiti izraz "pisac", ali on ne pokriva značenjsko polje kao u novovjekovnoj produkciji.

${ }^{4}$ Transliteracija glagoljskih tekstova provedena je prema načelima za izradu Rječnika crkvenoslavenskoga jezika hrvatske redakcije što ga priprema i izdaje Staroslavenski institut u Zagrebu; kratice su razriješene. 
e biti meštrom '). Pisanost i govorenost, odnosno usmenost ${ }^{5}$ srednjovjekovne tradicije isprepliću se i u ovom momentu, ukazujući na horizontalnu usmjerenost naših starih tekstova, za koje su pisci smatrali da trebaju biti fiksirani u pisanom mediju - bilo da je riječ o neaktualiziranom prenošenju predloška u vlastiti rukopis, ili pak o prilagodbi. Nabožna je književnost - a hrvatskoglagoljska književnost velikim je dijelom takva - usmjerena na više učinaka, ona je polifunkcionalna (pouka, poticaj, primjer, upozorenje, ushit i sl.). Jedan od razloga tomu jest da se redovito piše "za druge"; ovih'knigah'vašei ljubvi prikazuju zapisao je anonim u Petrisovu zborniku iz 1468. godine.

\section{Pod stolom ' meštra mrvice pobrah'}

Omiljenu srednjovjekovnu metaforu čitanja i pisanja (u smislu oblikovanja novih djela) kao hranjenja anonimni je glagoljaš u Petrisovu zborniku prenio i u našu sredinu. S toga stola, s te trpeze nudi se hrana (duhovna $\mathrm{i}$ intelektualna, ali i s estetskim signalima) a glagoljaš pobire tek mrvice, svjestan svoje nedostatnosti; ipak, to je kruh kojim će nahraniti svoju publiku, da i mi nastavimo istu metaforu. O sebi dakle piše skromno, a u metaforu hranjenja uključuje i daleke biblijske odjeke: mrvicama sa stola hrane se psići (Mt 15, 27; Mk 7, 28) i siromašni, bolesni Lazar (Lk 16, 21). Odnos prema baštini, prema izvorima koje prevodi, iz kojih prepisuje i kompilira ih, jest odnos poštovanja. Pritom autoritet koji se cijeni ili kojemu se divi ne mora biti osoba, već određeni tekst i/ili sadržaj što ga on prenosi. Naglašavajući poštovanje prema starim tekstovima i njihovu autoritetu, pisar/kompilator sebe sama također stavlja na određenu poziciju unutar tekstne zajednice - na neki način ima višu funkciju ili položaj o odnosu na primatelje, jer je mogao od meštara učiti i preuzimati. Dakle, usprkos toposu poniznosti i možda skučenom obrazovnom materijalu, na što se često pozivaju i ponavljaju, razvidno je kako su hrvatski glagoljaši imali pristup raznim predlošcima koje su prilagođavali za svoje rukopise. ${ }^{6}$

Hrvatski su glagoljaši osim toga bili svjesni kako svoje kulturno nasljeđe baštine od iznimnih ličnosti (mislilaca, teologa, učenjaka, filologa ali i svetaca) kao što su sv. Ćiril i Metod, ili pak sv. Jeronim. Kadšto ih izrijekom označavaju "našijencima", jer je Jeronim Hrvat, (kako piše u Petrisovu zborniku: čtenie s(ve) t(a)go Eronima Hrvatina), a Sv. Braća su Solinjani (kako se navodi u Mavrovu

${ }^{5}$ O signalima usmenosti i performativnosti usp. npr. M.-A. DÜRRIGL 2015a; M.-A DÜRRIGL 1015b za pripovjednu književnost te A. RADOŠEVIĆ, 2015 s obzirom na (prijevodnu) propovjednu materiju sačuvanu u hrvatskoglagoljskim kodeksima.

${ }^{6} \mathrm{O}$ glagoljaškim skriptorijima općenito usp. I. BOTICA et al., 2021, 437-441. 
brevijaru) - bez obzira na to, ti su sveci i velikani u hagiografskoj maniri u sebi spojili actio i contemplatio. Plodovi njihova rada osjećaju se kroz dugo vrijeme: i "danas" kad glagoljaši pišu svoje zapise, i "danas" kad ih mi čitamo i analiziramo.

Nerijetko su temeljni uzori za oblikovanje kakova-takova književnoga izraza ili stilskoga repertorija glagoljaša bili liturgijski tekstovi. Liturgija je u više smjerova bila ne samo slavljenje Boga, već i izvor obrazovanja. U katoličkoj srednjovjekovnoj tradiciji, liturgija je bila glavni izvor pouke za laike, kako je pokazala npr. Evelyn Vitz, nazivajući taj proces učenja "osmozom". ${ }^{7}$ No, naglasak nije bio na apstraktnom znanju, već je temeljna zadaća bila obrazovanje (u smislu oblikovanja) određenoga tipa osobe, te poziv na određeni način ponašanja kao odgovor na sadržaje koje su čuli. Za hrvatsku glagoljašku sredinu to se može sažeti ovako: "Svećenici bi nedjeljom izgovarali u crkvi naglas molitve Očenaš, Zdravomariju, Vjerovanje i Deset zapovijedi da ih okupljeni upamte."8

Osim biblijskih i liturgijskih izvora, ${ }^{9}$ glagoljaši su prevodili i prerađivali raznorodne sastave, od poučnih traktata, do pripovjedne proze. Kako se izrazio Eduard Hercigonja: "Svaki je pisac morao sam iz raspoložive građe izdvojiti ono što je smatrao najpotrebnijim i najsvrsishodnijim"10, pa zaključuje: "morao je anonimni autor očito posezati za raznovrsnim rukopisima koji su zasebno ili u zajedništvu s nekom drugom građom sadržavali sve ono što je konačno ušlo u sastav zbornika"11. A ta činjenica, skupa s daljnjom autorovom tvrdnjom kako su sačuvani hrvatskoglagoljski tekstovi svjedočanstvo "o uvećanju potreba, duhovnom rastu čitateljstva glagoljaških sredina potkraj srednjega vijeka"12 ukazuje na mijene unutar korpusa ili fenomena što ga provizorno nazivamo

${ }^{7}$ E. B. VITZ, 2005, 21. Odnos vjernika-laika, većinom slabije učenih, prema Sv. pismu bio je pamćenjski i liturgijski, a spas je dolazio preko slušanja i sudjelovanja u obredima: "The point is not simply that most of the laity did not read and had no religious school other than the liturgy, but also that the liturgy was indeed a school." E. B. VITZ, 2005, 23.

${ }^{8}$ I. BOTICA et al., 2021, 432.

${ }^{9}$ Valja reći kako se nerijetko spotičemo o paušalne, nekritične ocjene kako su glagoljaši bili neuki i priprosti; doduše, novija književnopovijesna djela ne vrednuju ih više tako. Premda su se pisari sami tako određivali, to je valjalo prepoznati i kao topos, opće mjesto a ne "objektivno samoocjenjivanje". Značajno je i to što su prevodili i prilagođavali latinske liturgijske tekstove na crkvenoslavenski jezik, a ne na sebi blizak vernakular. Iz toga crkvenoslavenskoga preuzimali su figure i trope koji su utjecali na neliturgijska djela koja su također prevodili, prepisivali i kompilirali. Osim toga poznavali su i latinsku legendarno-hagiografsku, te talijansku i češku tradiciju.

${ }^{10}$ E. HERCIGONJA, 1994, 197.

${ }^{11}$ E. HERCIGONJA, 1994, 198.

${ }^{12}$ Ibid. 
hrvatskom glagoljskom čitateljskom zajednicom. Dapače valja ponoviti: "O hrvatskim glagoljašima uglavnom se govori kao o piscima, prevoditeljima, naručiteljima, no za osvjetljavanje njihovih uloga svakako je potrebno usmjeriti se prema njihovoj čitateljskoj aktivnosti" ${ }^{13}$ bez koje ne bi mogli "pobirati mrvice" koje će podastrijeti svojoj publici. Nažalost, o konkretnim se izvorima razmjerno malo zna; na temelju sačuvanih tekstova znamo da su glagoljaši imali pristup izvorima, ali često ne znamo kakvima: jesu li prepisivali starije predloške, jesu li sami prevodili tekstove, koji su im pritom bili postupci, iz kakvih su sve izvora kompilirali... Habent sua fata libelli, ali je kadšto ta (pri)povijest zakrivena.

U hrvatskoglagoljskim zbornicima nalaze se veoma raznorodni tekstovi i žanrovi, od dekretala i redovničkih uputa, preko hagiografskih tekstova, vizija i stihova, do poučnih sastava (bilo kratkih, moralističkih egzempala, bilo obuhvatnih kompilacija kao što je Lucidar) - katkada su oni složeni u određene tematske (rjeđe vrsne/žanrovske) blokove ili cjeline u zbornicima (npr. u Petrisovu zborniku), a katkada je netko kasnije takove već postojeće, napisane blokove uvezao, spojio u cjelinu, kao što je slučaj sa Žgombićevim zbornikom ili Vinodolskim zbornikom ${ }^{14}$. Na taj način pisari zbornika nastoje, baš kao i njihovi europski parnjaci, skupiti što više znanja i sadržaja u svoje rukopise, stvarajući tako cvêtb, vartal ili zrcalo. ${ }^{15}$

Metonimijski se može kazati kako je glagoljaš po svojoj nadarenosti i obrazovanosti prevodio određena djela, ali su ga vodili i ukus, senzibilitet i potrebe sredine u kojoj je djelovao. U tom je pravcu vjerojatno prerađivao i prilagođavao izvornike. Gledajući samo površinske morfološke promjene tekstova, možemo pretpostaviti da su se glagoljaši istovremeno služili raznim književnim i izvanknjiževnim kontekstima; na taj su način postajali kompilatorima. Kao nužna pretpostavka za sastavljanje zbornika - kao kompilacija različitih vrsta tekstova, od pravnih i poučnih do narativnih - morali su određeni tekstovi biti glagoljašima na raspolaganju i služiti im kao izvori iz kojih mogu crpiti i slagati u nove cjeline ${ }^{16}$. Nije riječ samo o vrelu tema i motiva, nego i stilskih elemenata i kompozicijskih postupaka.

${ }^{13}$ A. RADOŠEVIĆ - M.-A. DÜRRIGL, 2020, 212.

${ }^{14}$ Usp. J. VUČKOVIĆ - M.-A. DÜRRIGL, 2021, 189-190.

15 "[...] oni mahom donose raznorodan sadržaj, od narativnih sastava kojima današnji čitatelji uglavnom pripisuju obilježja književnoga teksta do raznih diskurzivnih moralnopoučnih poglavalja koja sse toliko udaljuju od današnjega poimanja književnosti da ih filolozi s književnopovijesnim interesima rijetko i uključuju u svoje analize." J. VUČKOVIĆ - M.-A. DÜRRIGL, 2021, 189. O jednom aspektu popularne metafore zrcala i zrcalnosti usp. M.-A. DÜRRIGL, 2016.

${ }^{16}$ Usp. M.-A. DÜRRIGL, 2007, 27-52. 
Ponešto labav, ali ipak prepoznatljiv zajednički književni model obilježava pisano stvaralaštvo na slavenskome idiomu u Hrvatskoj, od prvih sačuvanih spomenika iz 11./12. stoljeća do sredine 16. stoljeća. U toj se tradiciji zrcale neka opća stremljenja europske književnosti, ali su prisutne i posebnosti kao što su: prevladavanje vjerske tematike, prevaga tzv. niskoga stila (sermo humilis zbog široke, horizontalne - ponekad nazivane "pučkom" - usmjerenosti tekstova), miješanje žanrova, te izrazita prevaga proze nad poezijom u sačuvanim pisanim spomenicima.

U bitno integriranoj kulturi kao što je srednjovjekovna, u kojoj se literarnost još ne može izljuštiti iz praktičnosti, niti obrnuto, zapravo je ostvaren diskurs koji "prevodi" višu, klerikalnu kulturu u mentalne kategorije i predodžbe, ali i lingvističke forme laika. Za brojne sačuvane tekstove može se slikovito kazati kako su autori prenosili kršćansku doktrinu kroz razne žanrove, te kroz fabuliranje, pripovijedanje, opis, dijalog i kroz tipične likove. To su nabožni tekstovi koji su, međutim, na neki način nadišli svoju prvotnu praktičnu funkciju i preživjeli do u naše dane kad ih se može sagledavati kao verbalne estetske ostvaraje. Valja ponoviti da u srednjemu vijeku općenito nije bilo razlikovanja praktično-estetsko u smislu sučeljavanja i međusobnoga isključivanja. Uostalom, riječ je o bitno pred-pismenoj kulturi što će imati odraza na oblikovanje tekstova; valja misliti o retoričnosti te produkcije koja se suvremenom čitatelju može postaviti kao problem. Pritom neprikladnost isticanja dihotomije estetsko/ praktično treba uvijek imati pred očima, jer je njihovo supostojanje bitni dio drugosti srednjovjekovne književnosti. Jedno ne potire ili isključuje drugo, osobito kad je riječ o nekim hagiografskim ostvarajima.

\section{To pisa ruka greš'na}

Tako je istaknuo pop Petar Fraščić sastavljajući psaltir s tumačenjem, u literaturi poznat kao Fraščićev psaltir ${ }^{17}$, kao da se grešan unaprijed ispričava, opravdava za omaške koje se mogu dogoditi.

Tek nekoliko primjera iz drugih izvora: očiti su primjeri pisarske pogreške

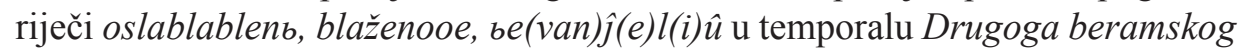
brevijara i riječi prizovovet', vititikanii, upfvanie, kamameniê u sanktoralu

\footnotetext{
${ }^{17}$ Naoko čudno; naime, ako sastavlja psaltir s tumačenjem znači da zapisuje tekstove koji imaju izniman autoritet, pa se pretpostavlja da piše s velikom pomnjom. No, upravo su zato moguće pogreške nešto za što se unaprijed treba ispričati jer ih se naprosto i očekuje kad se prevodi, prilagođava i prepisuje tekst koji je doista bio autoritet, potaknut i oblikovan Božjim nadahnućem. Usp. A. MINNIS, 2010, 40-72.
} 
Drugoga beramskog brevijara; nerazumijevanje izvora ili prepisivanje već nejasnoga mjesta, npr. hodola mogor umj. Hodolamogor u Drugome beramskom brevijaru ili ptica puniza u Petrisovu zborniku (riječ je o ptici feniks, koja se pojavljuje u Varuhovu viđenju); nepoznavanje materije o kojoj se piše, npr. monstrum sangvinis (u Lucidaru iz Žgombićeva zbornika, umj. menstruum sanguinis, glagoljašu je monstrum očito poznat, ali ne i druga riječ, a osobito ne pitanja humane reprodukcije). ${ }^{18}$

S druge strane, izraz ruka greš'na upućuje na shvaćanje po kojemu su grešni svi ljudi, pa tako i svi članovi i tekstne ali i (zamišljene, pretpostavljene) kršćanske zajednice kojima su namijenjeni sastavi većim dijelom nabožne tematike. Odnosi se to na opći moralizatorski ton koji se očituje kroz stalno naglašavanje grešnosti i potrebe za ispravljanjem života. U tom se smislu pisac, kompilator stavlja na istu razinu kao primatelj. To "mi" često progovara iz egzordijalne topike glagoljskih tekstova.

Dakle, greš'ne ruke sastavljale su knjige u kojima se zatječu sastavi koji i danas mogu probuditi interes ne samo stručne publike. Uza sve ograde i moguće nedostatke, u pripovjednim (u manjoj mjeri i u nekim poučnima) tekstovima prepoznaju se nastojanja oko stilskoga ukrašavanja kao svjesnoga nastojanja. ${ }^{19}$ Ono se prepoznaje već na osnovnoj jezičnoj razini. Raščlanjujući moguće stilogene elemente ${ }^{20} \mathrm{u}$ izmjeni narodnih i crkvenoslavenskih oblika Eduard Hercigonja piše: "Nema sumnje da se takvim postupcima postizavao specifičan dojam na slušateljstvo: crkvenoslavenska je riječ svojim iznenadnim probljescima kroz narodnu fakturu propovijedi budila pažnju, djelovala kao poticaj na percepciju primaoca"21, a to osobito vrijedi i šire za biblijske citate i odlomke ubačene u tkivo pripovjednoga teksta. Iz ovako rekonstruiranog postupka vidi se da je prvotno bio pisani tekst, koji se onda mogao govoriti, kombinirati s drugim tekstovima.

Sámo nabrajanje figura i tropa ne dokazuje umjetničku vrijednost nekoga teksta, ali treba na ovom mjestu istaknuti najčešće stilske postupke kao ilustraciju nastojanja naših glagoljaša oko umjetnosti riječi. To su: figure ponavljanja

${ }^{18}$ Usp. M.-A. DÜRRIGL, 2006.

${ }^{19}$ Usp. M.-A. DÜRRIGL, 2013; D. FALIŠEVAC, 1980.

20 U proučavanju stilistike hrvatskoglagoljskih tekstova seminalna je studija: E. HERCIGONJA, Iz radova na istraživanju sintakse i stila nekih glagoljskih neliturgijskih kodeksa XV. stoljeća, Radovi Zavoda za slavensku filologiju, Zagreb, iz 1965. godine, 119-139. I u brojnim drugim radovima, kao i u monografiji o hrvatskoj srednjovjekovnoj književnosti iz 1975. godine, Hercigonja redovito upućuje na estetske signale i uznačenja u raznorodnim tekstovima iz hrvatskoglagoljske baštine.

${ }^{21}$ E. HERCIGONJA, 1975, 39. 
i paralelizama (na različitim razinama od morfološke do rečenične), te figure (toposi) nadmašivanja $i$ neizrecivosti. Ovamo spadaju primjerice vrlo česte dijade, trijade; homeoteleut je izrazito prisutan kao jedna od figura ponavljanja i eufonije (aliteracije, asonancije), paregmenon i poliptoton. Topos nadmašivanja veoma je čest, kao i uporaba elativa ("predragi utêšitelju", "prečasnaê duše", "prev'zljubleni gospodine" primjeri su iz eshatoloških vizija). Nije rijedak ni topos neizrecivosti, jer često ono o čemu se pripovijeda nije izrecivo, pa čak ni prispodobivo ljudskomu jeziku, što je osobito čest - dapače očekivan - postupak u vizijama Onostranosti: npr. "i vidê toliko straš'ne rêči ke se ne mogu izgovoriti", "ke slave nigdore ne more ispovêdati", "i tu slišasta takove rêči kih' se ne podoba človêku govoriti". Česti su u našim tekstovima tzv. polisindetski nizovi čime se ostvaruje specifičan ritam kretanja kroz tekst, pa se tim postupkom također usmjerava pozornost primatelja i pomaže im se da se usredotoče na sadržaj, istodobno im pomažući u pamćenju i razumijevanju teksta.

Od tropa prisutne su brojne antiteze i gradacije, najčešće u vizijama i svetačkim martirijima; obje su česta strukturna načela naših srednjovjekovnih tekstova. Antiteza se očituje na različitim razinama, od fonološke do kompozicijske, česta je kao gradbeno načelo u vizijama, ali i u svetačkim pasiijama. Ironija je također zastupljena, a pridjevi/epiteti vrlo se često rabe u funkciji simbola, što iskazu daje višeznačnost i konotativnost. Metafore, parabole, poredbe i druga sredstva očuđenja ili prenesenoga značenja također se nalaze u našim pripovjednim tekstovima. To je posljedak nastojanja oko slikovitosti i dojmljivosti iskaza, ali i činjenice kako je u srednjem vijeku zemaljsko i božansko, profano i sveto bilo stalno povezano i prodiralo jedno u drugo.

Osim toga, u predpismenoj i bitno memorijalnoj kulturi kakva je srednjovjekovna neki su postupci mogli pomoći u pamćenju i usvajanju raznih tekstova i/ili njihovih dijelova, a oni su se mogli ili meditirati/promišljati ili pak po sjećanju govoriti nekoj publici. U tom smislu je čitanje kao prikazivanje ne samo nešto zapisano što se moglo "izvoditi" pred publikom u određenoj situaciji, već je mnogo širi pojam. U hrvatskoglagoljskoj srednjovjekovnoj tradiciji pisano i usmeno supostoje, a tekstovi su prenošeni $i$ usmeno/auditivno $i$ pismeno/ čitanjem u sebi. Tekstovi su bili u bitnoj mjeri namijenjeni za širi auditorij koji je trebao posrednika između sebe i zapisanoga teksta. Ono što je neupitno jest da su se izvoditi mogli tekstovi pripadni različitim pripovjednim žanrovima, pa se može kazati da je usmenost u velikoj mjeri ravnodušna prema kategoriji žanra.

Osim signala usmenosti i performativnosti, nalaze se u rukopisima nedvojbeni signali knjiškosti npr. tradicionalni gramatičko-sintaktički elementi 
kao dativ apsolutni, aorist imperfektivnih glagola ili imperfekt svršenih glagola, itd. Stoga nije moguće kazati da je hrvatskoglagoljska produkcija ili pisana ili usmena, već je ona oboje. Usmenost se dosad previše promatrala u kontekstu narodne književnosti i povezanosti s folklorom. Tih je dodira dakako bilo, ali ih ne valja apsolutizirati. Jer stilski staccato o kojemu često piše Hercigonja (uporaba polisindeta, paralelizama, ponavljanja) nisu značajka samo narodne književnosti, već ih nalazimo i u djelima francuskih trubadura - to je veza $s$ memorijom, s izvedbom/prelekcijom, s auditivnim primanjem sadržaja. Ne valja stoga naglašavati jaz pisano-usmeno (gdje bi pisanost bila povezana uz viši stupanj obrazovanja i viši društveni status, a usmenost uz "pučko"), jer su ta dva područja bila povezana.

Iako možda greš’ne, brojne su ruke marljivo pisale različite tekstove, $\mathrm{s}$ više ili manje umješnosti i nastojanja oko ukrašavanja izraza. Međutim, ako se i ne usuđuju nazvati piscima (kako npr. ističe fra Šimun Klimantović), glagoljaši osjećaju dužnost jer moraju pisati, i to najčešće drugima na nauk. I to je doduše topos, ${ }^{22}$ ali svakako odbljesak stvarnoga stanja u društvu: iole obrazovani glagoljaš treba za druge biti meštar, moistar, upravo magister.

\section{Nam'e biti meštrom'}

Na fol. 46 Petrisova zbornika piše: "nam'e(stb) biti meštrom'i prosveĉati plku tmu ki ništr'ne z'naju ni vêdê vole božie."

Uz simboliku svjetlosti (i opet omiljena srednjovjekovna metafora) izrijekom se navodi poučavanje: Svi su tekstovi nabožnoga značaja takvi da u njima etičnost ima važnu ulogu i zapravo prožimlje sve napisano. Tama koju meštrima valja prosvijetliti je neznanje, ali i nepoštivanje Božje volje. Stoga meštar treba u svom djelovanju povezati duhovno i svakodnevno, učenje i djelovanje. Iz sadržaja i stila glagoljskih knjiga koje su do nas došle čita se kako je svjetlost koju donosi po(d)učavanje vezana uz transcendentno, uz vječno $i$ božansko, a što može zahvatiti u život pojedinca, a izraziva je tek u slikama i približnostima, u pričama, tj. pripovjednim tekstovima. To je predokus vječnosti i kao takvo ima bitnu eshatološku dimenziju. Zbog toga valja tekstove čitati i

${ }^{22}$ I to je mjesto naslijeđeno od antike i čita se u nebrojenim umjetničkim tekstovima, ali je prepoznatljiva i biblijska referenca, npr. Mt 25,18 i dr. Jedan od najsnažnijih primjera je onaj sv. Hildegarde iz Bingena iz 12. stoljeća: od straha i skromnosti nije željela zapisati svoje vizije, pa bude teško bolesna, kao udarena Božjim bičem: "sed ego [...] in humilitatis officio scribere recusaui, quousque in lectum aegritudinis flagello Dei depressa caderem; ita quod tandem multis infirmitatibus compulsa [...] manus ad scribendum apposui." - HILDEGARDIS BINGENSIS SCIVIAS, 1978, 5. 
slušati, te ih pamtiti. Zato autorski pripovjedač na kraju "Dundulove vizije" u Petrisovu zborniku potiče primatelje da čuveno imaju vaz'da na vašoi dobroi pameti - dotični sadržaj valja imati stalno na pameti, zadržati ga u sebi; treba uvijek imati mogućnost prizvati u svijest, oživjeti i ponovo promišljati taj sadržaj i njegove poruke. Pamet i pamćenje u etimološkoj su vezi jer su sjećanje (kao sposobnost zadržavanja sadržaja) i pamet (kao sposobnost da se misli i rasuđuje) povezani fiziološki i psihološki. Na taj su način odlomci iz Sv. Pisma, ali i fraze i sintagme iz drugih pročitanih tekstova, postajale "njihove" fraze, glagoljaški kompilatori i prevoditelji/prerađivači spontano su ih se prisjećali i primjenjivali te fraze ili asocijacije na određenu temu kad su stvarali "svoja" djela. Sjajan su primjer za to monolozi Smrti u prijevodu Slovu meštra Polikarpa (i Petrisovu zborniku i Ljubljanskom zborniku); kao i u latinskom izvorniku, i ovdje su puni citata i referencija na Sveto pismo, ali i druge autoritete.

Ponovit ćemo kako su knjige stoljećima diljem Europe bile čitane naglas, tj. iz njih se čitalo u određenoj prilici, za neku publiku, bilo za pouku, ganuće ili zabavu - tako se pisani medij stapao i prožimao s usmenim, odnosno "oživljavao" u dinamičnom odnosu zapisanoga teksta (kao djela nekoga autora, makar anonimnoga, te unutartekstovnoga pripovjedača), pripovjedača kao kazivača/ čitača, likova i publike. ${ }^{23} \mathrm{U}$ svim ovim instancama, kad je riječ o hrvatskoj glagoljskoj baštini, još uvijek ima otvorenih pitanja.

U glagoljskim se zbornicima prepoznaju razne re-kombinacije, mala odstupanja ili veća, u popularnim ostvarajima koji su pisani (prepisivani, prevođeni) na području od Pokuplja do Dalmacije (npr. prenje između Isusa i đavla u četirima glagoljskim zbornicima; ${ }^{24}$ već spomenut razgovor meštra Polikarpa u dvama zbornicima gdje se sitne razlike ne mogu svesti samo na oštećenja stranica i sl.), varijacije, kraćenja, dodavanja, sitne razlike: jesu li one rezultat interpretacije ili različitoga predloška? Možda čak i zapisivanja po sjećanju? Bez obzira na činjnicu da ova pitanja još ostaju otvorena, ipak je moguće zaključiti kako su razlike takve vrste i opsega da pripovjedne zborničke

${ }^{23}$ Jer drukčiji je i način primanja auditivni (drugi centri u mozgu se aktiviraju) nego kod čitanja, ali mi danas možemo proučavati samo zapisane tekstove - usmenost sagledavamo kao potencijalnu kategoriju upisanu (oksimoron?) u tekst. (usp npr. BRADBURY, 1998 i DUYS et. al., 2015.

${ }^{24}$ Tekst dolazi pod različitim zaglavljima: "Učenie n(e)dile prve posta po Mateû" u tzv. Oxfordskom zborniku iz 15. st.; "Kako se e prelь d'êvals s G(ospo)d(i)nomb Is(u)h(rbst)omь" u tzv. Akademijinu zborniku iz 15. st.; "Čtenie peru nedelu korizmi" u tzv. Žgombićevu zborniku iz 16. stoljeća. Jedna je drukčija verzija bez naslova zapisana i u tzv. Berčićevu zborniku iz 15. stoljeća. - usp. izdanje S. SAMBUNJAK, 2000. 
tekstove nije moguće kritički izdavati kao npr. brevijarske legende, već u cjelini, susljedno. ${ }^{25}$

U kompilacijama hrvatskoglagoljskih zbornika iz 15. st. S. P. Novak prepoznaje da se pojavila "i kritička svijest sposobna da procjenjuje cjelovitost prethodne zatečene jezične i književne baštine. Događao se između korica tih kodeksa početak književnoga života u modernom smislu, začetak književnosti koja je bila sposobna misliti samu sebe, koja je bila svjesna svoje prethodne napisanosti i koja je tu svoju prethodnu napisanost sada još poželjela poboljšati i širiti." ${ }^{26}$ No, ako se podrobnije udubimo u memorijalni, pamćenjski karakter srednjovjekovne književnosti (ali i likovne umjetnosti), tada se postavlja pitanje o tome da tek u 15. st. glagoljaši postaju svjesni napisanosti svoje tradicije nisu li je oni zapravo i ranije bili svjesni? Napisanost naime te produkcije, bilo "književnosti" ili šire "pismene kulture" datost je prema kojoj se zauzimao određeni stav. Još je mnogo zadataka pred proučavateljima, osobito npr. kodikološke analize zbornika kao cjelina. ${ }^{27}$

Pođemo li suprotnim pravcem razmišljanja, nameće se pitanje jesu $l i$ srednjovjekovni autori doista bili svjesni literarne kvalitete starijih tekstova? Odnosno, je li to doista bila literarna svijest o kojoj je moguće govoriti u mlađim stilskim epohama? Učitavamo li previše u zbornike 15. stoljeća, osobito ako pogledamo ukupnost sadržaja koje oni u sebi kriju? Ako gledamo samo s književnopovijesnoga stajališta, ili ako pozornost usmjeravamo samo na tekstove s estetskim kvalitetama, iz vidokruga će izostati mnogobrojni "kapituli" i "čtenja" koji su pisani bez literarnih pretenzija, ali koji su važni za rekonstrukciju ili (pre)poznavanje bitnih odrednica knjiške glagoljaške kulture. Ili je pak i ovdje prisutan veliki problem koji ćemo nazvati "babilonizacijom" književnoteorijske terminologije - riječ je katkad o pojmovima koji se rabe i za srednjovjekovnu produkciju, ali joj ne odgovaraju u punoj mjeri. S druge strane, isti se termini mogu upotrebljavati za različita značenja, ili se suprotno znanstvenici spore "nominalistički", a da su im zapravo pogledi veoma bliski. Nije naime sasvim jasno jesu li ti termini, skovani i skrojeni po mjeri novovjeke književnosti, dovoljno fleksibilni kako bi mogli biti primjenjivani na srednjovjekovne tekstove, sa svim njihovim specifičnostima. Dakle, nije dvojba o tome da je pojam o lijepome, o literarnome bio prisutan; dvojba je samo o tome

\footnotetext{
${ }^{25}$ Usp. J. VUČKOVIĆ - M.-A. DÜRRIGL, 2021. Usp. primjerice izdanja hrvatskoglagoljskih prenja u S. SAMBUNJAK, 2000.

${ }^{26}$ S. P. NOVAK, 1996, 324.

${ }^{27}$ Usp. npr. R. STAMMBERGER, 2003.
} 
u kojoj mjeri ga mi možemo iščitati i pokazati, ako ga već ne možemo egzaktno dokazivati.

Teško nam se, zapravo i nemoguće, poistovjetiti s nosiocima toga izraza, ali pretpostavljamo kako je namjera tekstova u dobroj mjeri bila da služe egzemplarno - ipak, ne možemo znati kakav je bio stvarni "učinak" tih tekstova na primatelje. Glagoljaški meštri neumorno potiču i ne valja smetnuti s uma kako su, usprkos toposu skromnosti, uživali ugled svojim radom, ne samo pastoralnim već podukom i propovijedanjem. A kadšto je pripovijedanje u legendama, vizijama i apokrifima bilo na neki način kao fabularno, dramatično upozoravanje, pozivanje, poticanje, poduka. Jedan od brojnih primjera je i alegorijsko prenje između personificiranih četiriju Božjih kćeri (Milosti, Istine, Pravde i Mira) u tzv. Akademijinu zborniku - u okviru književnoga teksta nalazi se i poučni dio koji međutim nije samo moraliziranje, već eksplikacija na višoj razini s pozivanjem na brojne citate iz Sv. Pisma i crkvene autoritete, kod tumačenja antropomorfnih Božjih atributa (npr. milosrdan je, ali i pravedan). Publika za taj tekst vjerojatno ipak nije bila ona koja ništr' ne zna - dakle, može se kazati kako su zapisivani raznorodni tekstovi za različitu publiku.

Glagoljaški su kompilatori kao uvjereni kako su neznanje (!) i nepoznavanje Božje volje grijeh, pa nastoje zapisati tekstove koji će biti na umno, duševno, ali i osjećajno dobro publike - i one konkretne i naraštaja koji dolaze. Dakle, grijeh je ostaviti ljude u neznanju, odnosno ne podijeliti vlastito znanje, podijeliti mrvice sa stola starijih meštara. ${ }^{28}$ Pritom će anonimni sastavljač Petrisova zbornika ostaviti rukopis koji kao da stremi srednjovjekovnom idealu univerzalne knjige, jer je na svojim stranicama fiksirao i crkvenopravne tekstove i egzempla, zatim nabožna književna, pripovjedna djela (apokrife, legendarnohagiografske ostvaraje, vizije, Marijina čudesa, prenja), te tekst iz domene svjetovnoga s odzvucima viteške kulture kao što je Trojanida. Tako su meštri po svojim mogućnostima bili u specifičnoj službi unutar tekstne zajednice.

\section{Završni osvrt - a ê hoĉu kako mogu}

Na kraju ponavljamo citat iz naslova, a koji je uzet iz Petrisova zbornika: a ê hoĉu kako mogu. Tako, pomalo rezignirano, možda s mrvicom humora, ali ne bez hrabrosti i odlučnosti piše glagoljaš. $U$ tom iskazu prestaje uspoređivanje s drugima (u prije navedenim citatima pisar/kompilator/prevoditelj pobire tek

\footnotetext{
${ }^{28}$ Kako se čita već u Pravilu sv. Benedikta, opat će na Sudu odgovarati ne samo za svoja djela i moguće propuste, već i za (ne)djela povjerenoga mu stada - glagoljaški meštri ne žive zatvoreni, izolirani, već su aktivni članovi svojih zajednica, za njih se osjećaju odgovornima.
} 
mrvice, grešan je i neznatan, neka drugi isprave njegove pogreške, neka ga čitatelj ne kune i sl.), makar izraženo i kroz opća mjesta, kroz iskaze koji su možda bili neka vrsta "etikecije", nešto što se očekivalo. U potonjem citatu ta poniznost izostaje; u lapidarnom iskazu pisac, autor, kompilator kao da stupa pred nas, pred čitatelje i slušatelje svjestan svojih ograničenja, ali svjestan i zadaće koju ima: da poučava, i to u raznim smjerovima. Ako glagoljaš i nije učen, formalno obrazovan, knjiga koju je sastavio ima veliku vrijednost jer sadrži mudrost, a uz nju i ljepotu. Dakako, na temelju ovoga letimičnoga pregleda ne mogu se iznositi dalekosežne tvrdnje, ali otkrivaju se dojmovi, poput onoga o dubokoj povezanosti lijepoga i poučnoga (da tako kažemo, korisnoga).

$\mathrm{Na}$ temelju navedenih stilskih značajki nije moguće brzopleto donositi zaključke o literarnoj kvaliteti hrvatskoglagoljske produkcije, ali one su dostatne kako bi se ustvrdilo da nije bila riječ tek o pismenosti, niti samo o knjiškoj produkciji, nego da su naši glagoljaši nastojali oko umjetnosti riječi. Pritom je pisanju prethodilo čitanje - riječ je dakle ne samo o umješnim pisarima, već i obrazovanim prevoditeljima i piscima koji su znali preuzete sadržaje prilagoditi publici, ali isto tako nikad nisu zaboravili da ono kako pišu ovisi o tome što i za koga pišu. ${ }^{29}$ Oblik i stil morali su dostojno odraziti sadržaj i poruku. U tome se, kao i u otvorenosti suvremenim kulturnim stremljenjima u Europi, ogledaju literarni dosezi hrvatskih glagoljaša.

Estetska funkcija u hrvatskoglagoljskim religioznim tekstovima nije dominantna, ali ona jest ostvarena - u izboru i kombinaciji jezičnostilskih sredstava, u elementima kompozicije, u dijalogizaciji. To je bila bitno retorička književnost, jer je nastojala uvjeriti i potaknuti, a ne samo razonoditi, pružiti uzbuđenje ili ganuće, ne samo ispričati nešto iznimno. Književni je tekst (npr. hagiografski ostvaraj) mogao biti plodna podloga, poticaj za meditaciju o tome što život nekoga sveca može značiti "za mene" i za to "kako ću se ja" vladati. Odnosno: kako su se ponašali, kako su živjeli iznimni ljudi, sveci i svetice s kojima "ja" dijelim vjeru u Krista? U tom je smislu čitanje (ali zapravo i slušanje) bilo etičko i u tom smislu valja promatrati književne ukrase, trope i figure. Literarni se dosezi hrvatskih glagoljaša zrcale i u sposobnosti i spremnosti da prihvaćaju književne poticaje iz raznih kulturnih sfera i sredina, te da ih prilagođavaju svojoj publici; to je bila umjetnost riječi kao autentični izraz glagoljaša koji su bili umješni prevoditelji. No, suvremenim bi se rječnikom moglo reći: bez pretenzija, hoĉu kako mogu.

${ }^{29}$ Usp. A. RADOŠEVIĆ - M.-A DÜRRIGL, 2020. 
Tri podnaslova su citati koji su upravo opća mjesta europskoga srednjovjekovlja (neka očito naslijeđena od antike), a ovaj posljednji je lakonsko, pomalo šturo i odrešito, ali iskreno samoodređenje glagoljaša kakvoga mi danas zamišljamo. Svojim prijevodima i preradama kao postupkom kroz koji je ostvaren specifičan fenomen migracije, pokretljivosti i prilagođavanja raznih predložaka i izvora, glagoljaši su učinili hrvatsku glagoljsku pisanu riječ dijelom zajedničke europske srednjovjekovne kulturne, duhovne i književne tradicije. Plodove njihova rada valja nam i dalje izučavati.

\section{Literatura}

\section{Izvori}

Petrisov zbornik, 1468., Zagreb, Nacionalna i sveučilišna knjižnica, sign. $R 4001$

Vinodolski zbornik, poč. 15. st., Zagreb, Arhiv Hrvatske akademije znanosti i umjetnosti, sign. III a 15

Ljubljanski zbornik, kraj 15. st., Ljubljana, Nacionalna in univerzitetna knjižnica, Slav. Sammlung, fut. 3, br. 368

Akademijin zbornik, 15. st., Zagreb, Arhiv Hrvatske akademije znanosti i umjetnosti, sign. IV a 48

Žgombićev zbornik, 16. st., Zagreb, Arhiv Hrvatske akademije znanosti i umjetnosti, sign. VII a 30

Fraščićev psaltir, 1463., Beč, Österreichische Nationalbibliothek, sign. Cod. Slav. 77

Mavrov brevijar, 1460., Zagreb, Nacionalna i sveučilišna knjižnica, sign. $R 7822$

Drugi beramski brevijar, 15. st., Ljubljana, Nacionalna in univerzitetna knjižnica, sign. MS 163

\section{Knjige i članci}

Mile BOGOVIĆ, Okolnosti pojave i razvoja glagoljice na hrvatskom području do 1248. godine, u: Marija-Ana DÜRRIGL - Milan MIHALJEVIĆ - Franjo VELČIĆ (ur.), Glagoljica i hrvatski glagolizam. Zbornik radova s međunarodnoga znanstvenog skupa povodom 100. obljetnice Staroslavenske akademije i 50. obljetnice Staroslavenskog instituta, Staroslavenski institut - Krčka biskupija, Zagreb Krk, 2004, 247-260.

Ivan BOTICA - Tomislav GALOVIĆ - Elvis ORBANIĆ, Beram, župa Pazinskoga vikarijata u Porečkoj biskupiji te kòmun i Städtl Pazinske knežije u Habsburškome Carstvu do sredine 17. stoljeća, u: Milan MIHALJEVIĆ - Andrea RADOŠEVIĆ (ur.), Studije o Drugome beramskom brevijaru, Staroslavenski institut, Zagreb, 2021, 379-453. 
Nancy BRADBURY, Writing Aloud: Storytelling in Fourteenth-Century England, University of Illinois Press, Champaign-Urbana, 1998.

Eamon DUFFY, The Stripping of the Altars: Traditional Religion in England 1400-1580, Yale University Press, New Haven - London, 1992.

Marija-Ana DÜRRIGL, O prirodnofilozofijskim zapisima vezanima uz ljudsku reprodukciju iz hrvatskoglagoljskoga Lucidara, Acta medico-historica Adriatica 4, Rijeka, 2006, 13-25.

Marija-Ana DÜRRIGL, Čtirazumno i lipo. Ogledio hrvatskoglagoljskoj srednjovjekovnoj književnosti, Hrvatska sveučilišna naklada, Zagreb, 2007.

Marija-Ana DÜRRIGL, Hrvatska srednjovjekovna proza II. Apokrifi, vizije, prenja, Matijini mirakuli, Matica hrvatska, Zagreb, 2013.

Marija-Ana DÜRRIGL, Slovo meštra Polikarpa kao "monološki razgovor"- jedan pogled, Fluminensia, 27, 1, Rijeka, 2015, 155-169. (=Dürrigl 2015a)

Marija-Ana DÜRRIGL, Signali usmenosti hrvatskoglagoljskih pripovjednih tekstova, u: Vesna BADURINA STIPČEVIĆ - Sandra POŽAR - Franjo VELČIĆ (ur.), Hrvatsko glagoljaštvo u europskom okruženju, Staroslavenski institut, Zagreb, 2015, 467-481. (=Dúrrigl 2015b)

Marija-Ana DÜRRIGL, Pogled na Petrisov zbornik kao zrcalo, u: Tanja KUŠTOVIĆ - Mateo ŽAGAR (ur.), Meandrima hrvatskoga glagoljaštva. Zbornik posvećen akademiku Stjepanu Damjanoviću o 70. rođendanu, Hrvatska sveučilišna naklada, Zagreb, 2016, 95-108.

Kathryn A. DUYS - Elizabeth EMERY - Laurie POSTLEWATE (ur.), Telling the Story in the Middle Ages. Studies in Honor of Evelyn Birge Vitz, D. S., Brewer, Cambridge, 2015.

Dunja FALIŠEVAC, Hrvatska srednjovjekovna proza, Hrvatsko filološko društvo, Zagreb, 1980.

Adelgundis FÜHRKÖTTER - Angela CARLEVARIS (ur.), HILDEGARDIS BINGENSIS SCIVIAS, Brepols, Turnhout, 1978.

Eduard HERCIGONJA, Iz radova na istraživanju sintakse i stila nekih glagoljskih neliturgijskih kodeksa XV. stoljeća, Radovi Zavoda za slavensku filologiju, Zagreb, knj. 7, 1965, 119-139.

Eduard HERCIGONJA, Povijest hrvatske književnosti 2: Srednjovjekovna književnost, Liber - Mladost, Zagreb, 1975.

Eduard HERCIGONJA, Trojezična i tropismena književnost hrvatskoga srednjovjekovlja, Matica hrvatska, Zagreb, 1994.

Alastair MINNIS, Medieval Theory of Authorship. Scholastic Literary Attitudes in the Later Middle Ages, University of Pennsylvania Press, Philadelphia, 2010.

Slobodan P. NOVAK, Povijest hrvatske književnosti I. Od početaka do Krbavske bitke 1493., Izdanja Antibarbarus, Zagreb, 1996.

Andrea RADOŠEVIĆ, O nekim signalima usmenosti u glagoljskim propovijedima iz 15. i 16. stoljeća, u: Vesna BADURINA STIPČEVIĆ - Sandra POŽAR - Franjo 
VELČIĆ (ur.), Hrvatsko glagoljaštvo u europskom okruženju, Staroslavenski institut, Zagreb, 2015, 483-496.

Andrea RADOŠEVIĆ, Ici $i$ fra Ruberti - propovijedi kao glagoljaška lektira, u: Tanja KUŠTOVIĆ - Mateo ŽAGAR (ur.), Meandrima hrvatskoga glagoljaštva. Zbornik posvećen akademiku Stjepanu Damjanoviću o 70. rođendanu, Hrvatska sveučilišna naklada, Zagreb, 2016, 459-470.

Andrea RADOŠEVIĆ - Marija-Ana DÜRRIGL, O glagoljskoj čitateljskoj zajednici na primjeru Drugoga beramskog brevijara, Slovo, 70, Zagreb, 2020, 191-216.

Slavomir SAMBUNJAK, Jezik $i$ stil hrvatskih glagoljskih prenja, Književni krug, Split, 2000.

Ralf STAMMBERGER, Scriptor und Scriptorium. Das Buch im Spiegel mittelalterlicher Handschriften, Akademische Druck- u. Verlagsanstalt, Darmstadt, 2003.

Evelyn B. VITZ, Liturgy as Education in the Middle Ages, u: Ronald B. BEGLEY Joseph W. KOTERSKY (ur.), Medieval Education, Fordham University Press, New York, 2009, 20-34.

Josip VUČKOVIĆ - Marija-Ana DÜRRIGL, Nacrt za usporedno istraživanje uloge brevijara i zbornika u povijesti hrvatskoglagoljske knjige, u: Milan MIHALJEVIĆ - Andrea RADOŠEVIĆ (ur.), Studije o Drugome beramskom brevijaru, Staroslavenski institut, Zagreb, 2021, 179-211.

\section{A Ê HOĈU KAKO MOGU - A FEW THOUGHTS ABOUT CROATIAN GLAGOLITIC WRITTEN HERITAGE}

\section{Summary}

In the paper are briefly summarised some views of the community who used the Glagolitic text, based on several typical statements of Glagolitic scribes, compilers and translators. From the selected quotations the connection of the diverse content of the manuscripts is revealed (some of them are arranged according to the ideal of "as general as possible" material, as though aiming at some kind of mediaeval encyclopaedism, to which The Petris Miscellany from 1468 is the closest) with a definite environment, i.e. to the audience for whom the texts are written, and with the polyfunctionality of a great number of transcribed, translated or compiled compositions.

It is a process through which the specific phenomenon of "migration", mobility and adaptation of various templates and sources was realised, whereby the Glagolitic writers or priests made Croatian Glagolitic written word part of the common European mediaeval cultural, spiritual and literary tradition.

Keywords: Croatian Glagolitic written heritage, reading community, scribes, miscellanies 